except by relying on humans for food. Therefore they stay near humans until they die or are shot. At this stage Great Horned Owls and Red-tails can be extremely dangerous. You have only to think of their strength to imagine what might happen if the bird should inadvertently land on a small child or pick at something in his hand.

Not only are we as falconers very much aware of the undesirability of keeping hawks and owls as pets, we are doing our best to eliminate this practice through legislation. We feel that the taking of young birds should be rigidly controlled through a permit system similar to the present collecting permit system. This would ensure the establishing of definite regulations and the enforcing of them. In the meantime, every one of us can make a personal effort to see that others become aware of the need for protection of our native birds of prey.

\title{
The Big Snow of October
}

\section{By Frank Brazier, Regina}

On October 8, 1959, a low pressure area formed in the Pacific Ocean off the coast of British Columbia and moved eastwards. Ahead of it the temperature dropped to $18^{\circ} \mathrm{F}$ and by morning an incl: of snow lay on the ground. After the low had moved inland a series of low pressure systems formed in the same original area and likewise moved inland so that a train of low pressure systems was created. The first in the series reached Regina about 7 a.m. on October 9 and by mid-morning it had started to snow in earnest, the wind increasing to 25-30 m.p.h. By noon of the 12th, snow 10.4 inches deep was underfoot. The disturbance finally extended to Battleford and Prince Albert in the north, the nortr-ern tier of states on the south and well into Ontario in the east. Western Manitoba actually bore the brunt as the systems stalled on the Turtle Mountains with the result that it snowed almost continuously, 30 inches piling up. After the 9th the wind was not troublesome but the temperature averaged $20^{\circ} \mathrm{F}$ minimum and $26^{\circ} \mathrm{F}$ maximum for tre four days. These low temperatures iced much of the Wascana Creek system except for the open water caused by the Regina power plant's warm discharge, and the odd puddle here and there.

The power plant discharge kept half of the Wascana Marsh ice-free which was a boon to migrating waterfowl, and they piled in there in thousands to wait for better weather. Some stretches of Wascana Lake likewise did not freeze and these too were crowded. The tail-end of the migration of other birds found conditions miserable but manageable and I saw no evidence of suffering. Myrtle and Orange-crowned Warblers gleaned the trees as did the kinglets and, surprisingly enough, the juncos. Hermit Thrushes and Robins went to work on the berry crop while White-throated Sparrows pecked into hanging fruit for the seeds. Most of the trees and shrubs still held their foliage wrich sheltered much of the ground from deep snow and in the hedges and under shrubs Harris and White-crowned Sparrows searched assiduously. Tree Sparrows and juncos fell on to weed heads while Purple Finches took samaras. Oddly enough I saw a House Sparrow also sampling the winged seeds of Manitoba Maple.

In Rotary Park, Wascana Creek remained open here and there where tree water moved more quickly, and here Rusty Blackbirds and Grackles hung about in disconsolate groups; over one patch of open water a Kingfisher maintained a watch while a couple of Greater Yellowlegs and three Common Snipe moved from one pool to the other. At one of these a Sora searched the mud, retreating at my approach under a curtain of overhanging grass on the creek bank into an old muskrat burrow. It was tastefully arrayed in a pair of crystal gaiters which rad formed as the water in which it waded froze its legs. This rail stayed until October 20 and when last seen appeared perky and in good spirits. During the most miserable day, the windy, snowy, cold 9 th, I noticed the Kingfisher sheltering in a large drain from which: he would make sorties to what open water remained. 
On October $11 \mathrm{I}$ stood on the bank of Wascana Lake watching the crowds of waterfowl on the open stretches - Mallards, Bufflehead, Ruddies, Gadwalls, Widgeons, Shovelers, Canvasbacks, Scaups, Goldeneyes, Blue-winged Teal, Eared, Horned and Pied-billed Grebes, Coots and gulls. Standing on the ice at the edge of the water was a Water Pipit and over the island a Sharp-shinned Hawk hovered and circled. Moving around the iake I eventually stood on the south bank looking north across a narrow channel to the island. A small stretch of open water was crowded with ducks, some of which immediately flew, but others, needing a run for a take-off, remained-three Pied-billed Grebes, three Ruddy Ducks, a female Scaup and four Coot. Idly scanning the group I noticed that one of the Coots was larger and then it turned its head and I saw two white patches on the head, and the profile of the bill-a scoter, but wkat kind? Much too small for a White-winged, so probably a Surf Scoter. An hour later I was back with Elmer and Reg Fox and a headful of facts-often the White-winged Scoter does not show the white in the wing at rest, and a large Surf Scoter is larger than a small White-winged Scoter. In a few minutes she told us which she wasshe sat on ker tail and flapped her wings vigorously: not a trace of white, so a Surf Scoter she must be.

There are not too many Surf Scoter records for SaskatchewanFred Lahrman lists six occurrences in The Blue Jay for March, 1958, and Dr. Stuart Houston reports Saskatchewan's "first resident bird watcher," Geo. F. Guernsey, in the following issue as taking a specimen in the fall of 1883 at Fort Qu'Appelle and classifying it then as a rare migrant, first arrival date May 1.

Another larger hawk was seen briefly that day in the Legislative Grounds but too briefly to determine species. However, at the Cameron Street footbridge a large poplar held a fine Rough-legged Hawk-so nice to see one of the large buteos in a colour phase.

That day Fred Lahrman found an Arctic Loon on the Marsh. Elmer and $I$ at that time did not see the loon close enough to identify it, but we found four unmistakeable Whitewinged Scoters, 2 Hooded Mergansers and a Red-breasted Merganser on the following day. During the week Fred found seven Hcodies, two Common Mergansers and two Arctic Loons. It was not until the following Sunday, the 18th, that I found one of the Arctic Loons patrolling the edge of a great duck raft; an hour later Elmer Fox and Betty Cruickshank were also viewing it, at close enough range to note the straight lower mandible as well as general plumage details. There have been only two previous records for the province, Kronau (1947) and Nipawin (1948).

Among the ducks were some Ringnecks and Redheads and even a Pintail drake. There were Fred's Canada Geese, 13 Pelicans, a Great Blue Heron and several Western Grebes. A lone Marsh Hawk hunted the reed beds wk:ile a rowdy gang of 15 Crows abused us from the nearby trees. While the storm did have the effect of halting waterfowl movement southwards, I could not see that it had any visible ill effects in Regina among the migrants.

\section{JUNCO RECOVERED IN ALASKA By S. Houston, Yorkton}

Since 1943 I have banded over 16,800 birds of 137 species, but a recent recovery of a Slate-colored Junco is one of the most exciting of all. It is my first recovery from 38.1 juncos banded, and the junco is the 29 th species for which I have a recovery. The junco was banded as an adult in our backyard banding station in Yorkton on October 3, 1957. It was. killed by a cat at Soldotna,
Kenai Peninsula, Alaska, on July 10, 1959 , and the band was given by its finder, Mel Carlson, to Mrs. Mary A. Smith, regional editor of Audubon Field Notes at Cohoe, Alaska. It had never occurred to me that some of the juncos that migrate through Yorkton are birds that breed in Alaska! This is another example of how a single banding recovery can be of great scientific interest. 